\title{
Evaluation of Some Properties of Heat Cure Acrylic Resin after the Addition of Salinated Aluminum Silicate Composite Filler
}

\author{
Raghdaa Kareem Jassim ${ }^{1}$, Aseel Abdulameer Radhi ${ }^{2}$ \\ ${ }^{1}$ Assistant Professor, College of Dentistry, University of Baghdad, Baghdad-Iraq, Corresponding author \\ ${ }^{2}$ Assistant Lecturer, College of Dentistry, University of Kerbella, Kerbella-Iraq
}

\begin{abstract}
Background: improvement of mechanical properties of heat cure acrylic resin with inorganic filler had great attention. The purpose of this study was to evaluate some mechanical properties of heat cure acrylic after the addition of salinated aluminum silicate Al2SiO5 filler in different concentrations. Materials and methods: A total 124 specimens were constructed, 30 specimens were prepared from heat cure PMMA without additives (control) and 90 specimens were prepared from heat cure acrylic resin with the addition of salinated $\mathrm{Al}_{2} \mathrm{SiO}_{5}$ composite filler which divided into 3test groups according to different percentage(3\%, 5\%, 7\%). Each group was divided into 10 sub-groups according to the test performed which was impact strength, surface hardness and surface roughness. Also for each group,4specimens were prepared for FTIR test. Results: The results of addition salinated $\mathrm{Al}_{2} \mathrm{SiO}_{5}$ particles to PMMA record a highly significant increase in impact strength, surface hardness and surface roughness. For impact strength test, the highest mean value was for specimens containing $3 \% \mathrm{Al}_{2} \mathrm{SiO}_{5}$. While for surface hardness test and surface roughness test, there is a marked increase in the mean values as the concentration of fillers increase. Conclusion: Within the limitation of this study, it may be concluded that the addition of 3\% Aluminum silicate to heat cure acrylic denture base material improves the impact strength, hardness with slight increases the surface roughness.
\end{abstract}

Keywords: aluminum silicate, fillers, heat cure, strength, roughness

\section{Introduction}

Poly methyl methacrylate (PMMA) acrylic resin material is preferably used for prosthodontic applications this mainly for its adequate aesthetics and desirable characteristics. It has adequate strength, low water sorption, low solubility and low thermal conductivity and it is free from toxicity ${ }^{(1)}$

However, the mechanical strength of acrylic resin is not sufficient to maintain the longevity of dentures, the main problems associated with PMMA as denture base material are poor strength and fracture due to imbalance occlusion inside the mouth, impact failure outside the mouth. ${ }^{(2,3)}$

In denture base, there are weak areas susceptible to fracture such as the midline of the palate,smallanterior area of the mandibular denture after severe resorption and high buccal and lingual frenal attachments that under gone fracture ${ }^{(4)}$ this problem lead to several attempts has been conducted in order to avoid denture fractures, such as increase the denture thickness. The $\mathrm{Co}-\mathrm{Cr}$ mesh reinforcement produced the highest transverse strength and the metal wire reinforcement produced the greatest increasing in impact strength and tensile strength. ${ }^{(5)}$

The use of flexible type of denture base materials such as polyamide(nylon) material which is known as a flexible acrylic demonstrate a great impact strength, toughness, and resistance to fracture ${ }^{(6)}$

Addition of a polyfunctional crosslinking agent to acrylic denture base material such as polyethylene glycol dimethacrylate ${ }^{(7)}$ or by incorporating a rubber phase ${ }^{(8)}$ or fibers ${ }^{(9)}$ in order to enhance the mechanical properties of denture base materials.

Attention has been directed toward the incorporation of inorganic fillers into acrylic resin to improve its properties. It was noted that reinforcement of PMMA with $2.5 \%$ of $\mathrm{Al}_{2} \mathrm{O}_{3}$ significantly increases the flexural strength and surface hardness of the resin while the surface roughness not differ from the control group ${ }^{(10)}$

Modification of heat-cured acrylic resins with certain amounts of metal oxides done by Neset et al in 2013 who added $\mathrm{Al}_{2} \mathrm{O}_{3}, \mathrm{TiO}_{2}$ and $\mathrm{ZrO}_{2}$ fillers in $1 \%$ and $2 \%$ by volume for each filler type resulted in significant increase in impact strength and fracture toughness and significant decrease in water sorption and solubility ${ }^{(11)}$

The problem with reinforcement of acrylic denture base with fillers is the adhesion failure ${ }^{(12)}$ so surface modification of an inorganic particle with an organic substance is a useful way to reduce its surface energy and increase its compatibility with polymer matrix and dispersion homogeneity and thus improve the properties of the polymer/ inorganic particles. ${ }^{(13,14)}$.

Inorganic filler aluminum silicate that used in this study has been found to be biocompatible material ${ }^{(15)}$, and can be simply processed with acrylic denture base material.

The aims ofthis study was to investigate the effect of addition aluminum silicate composite fillers into heat cure resin on some mechanical properties including: impact strength, hardness, and surface roughness. 


\section{International Journal of Science and Research (IJSR)}

ISSN (Online): 2319-7064

Index Copernicus Value (2015): 78.96 | Impact Factor (2015): 6.391

\section{Materials \& Methods}

2.1Surface modification of aluminosilicate (A12SiO5 $R$ ) with 3-methacrlyoylpropyl) trimethoxysilane (MPS)

One hundred milliliter of ethanol aqueous solution (70 vol\%) was prepared fromethanol (Carloerba, Rodano, Milano, Italy) 99.8 vol\% and deionized water.The PH was adjusted to 4.5 by titrating with acetic acid (Carlo erba, Milan, Italy) $99.9 \%$ by using a $\mathrm{pH}$ meter (ORION 420A, Orion Research Inc., Boston, MA, USA). Then, $1.5 \mathrm{~g}$ of MPS was added respectively into the ethanol aqueous solution, and stirred. This MPS solution was stored in a 100 $\mathrm{mL}$ polyethylene cup with a cover, and allowed $5 \mathrm{~min}$ for hydrolysis and silanol formation. Then $30 \mathrm{~g}$ of aluminum silicate powder (The British Drug Houses LTD.B.D.H. Laberayory Chemical Group Poole England) were added into MPS solution. The mixture was stirred until the solution was completely evaporated, and left dried at room temperature for 14 days. $^{(16)}$

The (FTIR) spectrophotometer (Shimadzu, FTIR-8400S Japan) was used to determine whether functional group of the MPS have been attached to fillersor not.This was appeared by analyzing characteristic vibrations of functional groups. ${ }^{(17)}$

\subsection{Specimens' preparation}

Two different metal patterns were constructed by cutting metal copper alloy plate in desired shape and dimension. For impact strength test, a bar shaped specimen (80X10X4) mm length, width, and thickness respectively. ${ }^{(18)}$ For hardness test, and surfaceroughness test: a bar shaped specimen $(65 \mathrm{X}$ $10 \mathrm{X} 2.5) \mathrm{mm}$ length, width, thickness respectively ${ }^{(19)}$

Mold for specimens used in this study was following the conventional flasking technique for complete denture.

\subsection{Proportioning and mixing of acrylic}

Amounts of polymer, monomer and silanized alumina silicate with percentages $3 \%, 5 \% \& 7 \%$ used in the study where weighted by using an electronic balance with accuracy of $(0.0001 \mathrm{~g})$. The proportioning of acrylic powder/ liquid ratio and the percentage of added filler was revealed in the table1.

Table 1 The proportioning of acrylic powder/ liquid ratio and the percentage of added filler

\begin{tabular}{|c|c|c|c|}
\hline $\begin{array}{c}\text { Al2SiO5 } \\
\text { percentage }\end{array}$ & $\begin{array}{c}\text { Amount of } \\
\text { Al2SiO5 }\end{array}$ & $\begin{array}{c}\text { Amount } \\
\text { of PMMA }\end{array}$ & $\begin{array}{c}\text { Amount of } \\
\text { monomer }\end{array}$ \\
\hline $0 \%$ control & 0 & $12 \mathrm{~g}$ & $6 \mathrm{ml}$ \\
\hline $3 \%$ test & $0.360 \mathrm{~g}$ & $11.640 \mathrm{~g}$ & $6 \mathrm{ml}$ \\
\hline $5 \%$ test & $0.600 \mathrm{~g}$ & $11.400 \mathrm{~g}$ & $6 \mathrm{ml}$ \\
\hline $7 \%$ test & $0.840 \mathrm{~g}$ & $11.160 \mathrm{~g}$ & $6 \mathrm{ml}$ \\
\hline
\end{tabular}

At this step filler mixed with acrylic powder according to Abdulkareem in 2016, ${ }^{(20)}$ Then the mixture of acrylic powder/ liquid was done and left to stand until a dough stage was reached. Then packed, flasked, and processed as conventional way for complete denture construction.
The specimens were grouped into one control group and 3 test groups.As shown in Figure1. Ten specimens for each group make a total of 40 specimens for each mechanical testing.

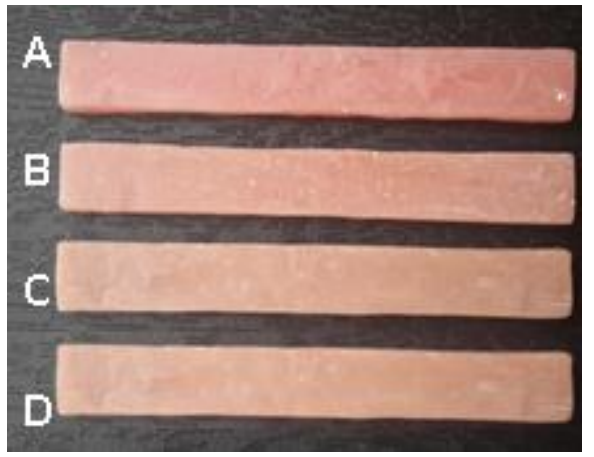

Figure 1: Acrylic specimens A. control specimen 0\% fillers B. acrylic specimen $3 \% \mathrm{Al}_{2} \mathrm{SiO}_{5}$ C.Acrylic specimen $5 \% \mathrm{Al}_{2} \mathrm{SiO}_{5}$ D.acrylic specimen $7 \% \mathrm{Al}_{2} \mathrm{SiO}_{5}$

\subsection{Mechanical properties tests}

In this research, Mechanical test includes the following:-

1-Impact strength test: this was conducted following the procedure given by the ISO 179 with charpy type impact testing instrument (Impact tester N. 43-1, INC. USA.). The specimen was supported horizontally at its ends ad struck by a free swinging pendulum which released from a fixed height in the middle. A pendulum of 2 joules testing capacity was used. The charpy impact strength of not notched specimen was calculated in $\mathrm{KJ} / \mathrm{m} 2$.

2-Surface hardness test: this was determined using durometer hardness tester from type shore D, (hardness tester-th 210, time group Inc. Italy) which is suitable for acrylic resin material. The instruments consist of bluntpointed indenter $0.8 \mathrm{~mm}$ in diameter that tapers to a cylinder $1.6 \mathrm{~mm}$. The indenter is attached to a digital scale that is graduated from 0 to 100 units; measurements were taken directly from the digital scale reading. Five measurements were done on different areas of each specimen (the same selected area of each specimen), and an average of five reading was calculated.

3- Surface roughness test: the profilometer device (Surface roughness tester SRT-6210, England)was used to study the effect of aluminum silicate filler reinforcement on microgeometry of the test surface. This device is supplied with surface analyzer (sharp stylus)made from diamond. Maximum distance that can be move is $11 \mathrm{~mm}$.Two measurements were done on different areas of each specimen(the same selected area of each specimen), and an average of two readings was calculated.

\section{Results}

FT-IR spectrum obtained from aluminosilicate composite indicated that the peak at 1,05699 confirming the formation of $\mathrm{Al}-\mathrm{O}-\mathrm{Si}$ bonds, and a peak at $443.63 \mathrm{~cm}^{-1}$, which is due to $\mathrm{O}-\mathrm{Si}-\mathrm{O}$ bending vibrations. The wide IR band in the range of $3,000-3,800 \mathrm{~cm}^{-1}$ is due to the stretching vibration of $\mathrm{H}_{2} \mathrm{O}$ molecules. Figure 2 .

\section{Volume 6 Issue 7, July 2017 www.ijsr.net}




\section{International Journal of Science and Research (IJSR) \\ ISSN (Online): 2319-7064}

Index Copernicus Value (2015): 78.96 | Impact Factor (2015): 6.391

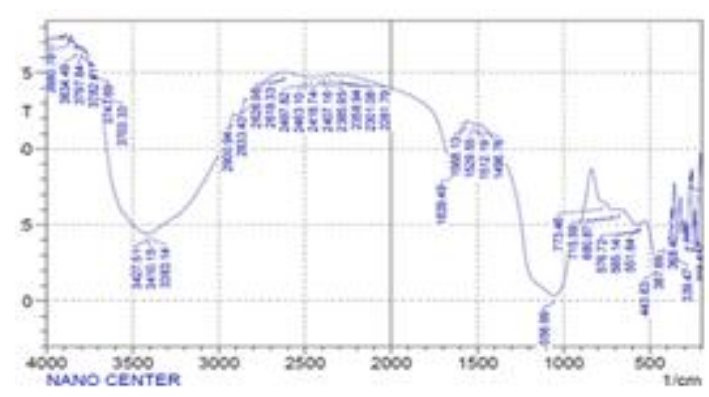

Figure 2: FTIR of aluminum silicate

The absorption bands of modified alumino silicate fillers has almost all the absorption peaks present in TMSPM, in addition to the peaks present in the aluminosilicate fillers. FTIR spectra of modified alumino silicate showed adsorption at $1,051.20 \mathrm{~cm}^{-1}(\mathrm{C}-\mathrm{H}), 1687 \mathrm{~cm}^{-1} \quad(\mathrm{C}=\mathrm{O})$, $1153 \mathrm{~cm}^{-1}(\mathrm{C}-\mathrm{O})$. This clearly indicated the existence of chemically bonded TMSPM on the alumino silicate fillers surface as shown in Figure3.

FT-IR silanated Aluminosilicate added to PMMA showed change the shape of adsorption peak at $1627 \mathrm{~cm}^{-1}(\mathrm{C}=\mathrm{C})$ of PMMA. As shown in Figure 4.

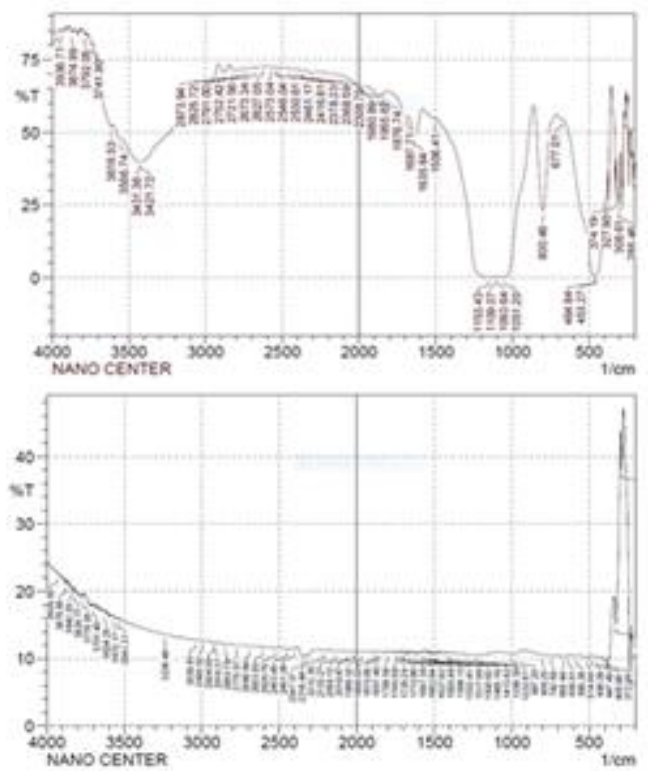

Figure 4: FTIR of silanated aluminium silicate added to polymethylmethaacrylate methacrylate

In this study, the comparison was done between unmodified acrylic resin sample (control group) and modified acrylic resin containing $3 \%, 5 \%$ and $7 \%$ salinized aluminum silicate composite particles. All data were subjected to a one-way analysis of variance (ANOVA) and followed by multiple comparisons by Bonferroni test method.

Table-2 shows the mean and standard deviation values of impact strength, surface hardness, and surface roughness for all experimental groups. For impact strength test, the highest mean value was $(0.288+0.02)$ for specimens containing $3 \%$ Al2SiO5 only. While for surface hardness test surface roughness test, there is marked increase in the mean values as the concentration of fillers increase. In ANOVA test, there is a highly significant differences among all tested group in all test (p-value=0.000).In table-3 Multiple compressions (Bonferroni test) among all tested group for impact strength mean values. The results shows a highly significant difference $(p$-value $=0.00)$ between mean values of each two tested group.

In table 4 , the results of surface hardness test shows a no significant difference between specimens contain 5\% $\mathrm{Al}_{2} \mathrm{SiO}_{5}$ and specimens contain $7 \% \mathrm{Al}_{2} \mathrm{SiO}_{5}$ only.

For surface roughness test, Table- 5 mention that there is a non-significance differences between mean values of a specimens contain $3 \% \quad \mathrm{Al}_{2} \mathrm{SiO}_{5}$ and control group $(0 \%$ $\mathrm{Al}_{2} \mathrm{SiO}_{5}$ ). And between groups contain $5 \% \mathrm{Al}_{2} \mathrm{SiO}_{5}$ and groups contain $7 \% \mathrm{Al}_{2} \mathrm{SiO}_{5}$.

\section{Discussion}

The fracture property of poly methyl methacrylate acrylic denture base material is not uncommon so studies to improve the strength of this material by addition of fillers still continued. The Addition of inorganic filler to acrylic denture base in different concentrations to improve its mechanical properties has been studied by many authors $(10$, 11)

One of these inorganic fillers alumina and silicate particles. ${ }^{(21,22)}$ For the aluminum silicate composite material it was proved their biocompatibility and its color white powder not affect esthetic of acrylic denture base. ${ }^{(15)}$

In this study the results of impact strength revealed that a highly-significant difference between control groups and the modified test groups. there is a slight increase in the mean value of $3 \%$ compared to control group this attributed to interaction between the silainated aluminum silicate fillers with PMMA matrix. As the matrix acts as impact modifier that it slight increases the ductility of PMMA matrix.

generally the mean values of impact strength decrease with increase the filler content in 5\% and $7 \%$ test groups compared to control, these results in agreement with Khalaf in $2013^{(23)}$ \&Ronak and Pranav in $2016 .^{(24)}$ Decreasing the mean values of impact strength with increase in concentrations of fillers.

The results of hardness test showed that an increase in the mean values with increase the amount of filler and show a highly significant difference between control and 3\%, 5\% and $7 \%$ Aluminum silicate test groups respectively, the possible explanation may be due to the aluminum silicate particles harder than acrylic polymer so increase inorganic filler per unit area of acrylic resin gives more resistance to indenter penetration and more hardness values obtained. Similar results were obtained by different authors who worked on different inorganic micro fillers that added to polymethyl methacrylate denture base material ${ }^{(25,26)}$

About the surface roughness the results showed a highly significant increase in surface roughness with increase the filler content this may be due to differences in particle roughness and microstructure of aluminum silicate compared to heat cure acrylic matrix these results agreed with Khalaf, 2013 ${ }^{(23)}$ and not agreed with Abdulhamed\&

\section{Volume 6 Issue 7, July 2017 www.ijsr.net}




\section{International Journal of Science and Research (IJSR) \\ ISSN (Online): 2319-7064}

Index Copernicus Value (2015): 78.96 | Impact Factor (2015): 6.391

Mohammed in $2010^{(27)}$ and Makarem $2015^{(28)}$ who revealed that the surface roughness of acrylic denture base was not significantly increased with the addition of $\mathrm{Al}_{2} \mathrm{O}_{3}$. So these differences may be regarded to differences in filler particle type and the method of mixing in both previous studies compared to this study.

\section{Conclusion}

Within the limitation of this study, it may be concluded that the addition of $3 \%$ Aluminum silicate to heat cure acrylic denture base material slightly increase but not significantly improve the impact strength of acrylic denture base. The impact strength decrease with increase particle percentage more than $3 \%$ compared with non-reinforced group.

Surface hardness and surface roughness of heat cure acrylic denture base increased with increased the amount of aluminum silicate particles.

\section{References}

[1] Goiato MC, Santos DM, Haddad MF, Pesqueira AA. Effect of accelerated aging on the microhardness and color stability of flexible resins for dentures. Braz Oral Res. 2010;24(1):114-9.

[2] Jagger D.C.; Harrison A. And Jandt K. The reinforcement of dentures J. Oral Rehabil 1999; 26: 185-194.

[3] Zappini G, Kammann A, and WachterW.Comparison of fracture tests of denture base materials. J Prosthet Dent. 2003; 90(6): 578-585.

[4] Meng TR andLatta MA. Physical properties of four acrylic denture base resins. J Contemp Dent Pract. 2005; 6:93-100.

[5] Bashi TK and Al-Nema LM. Evaluation of Some Mechanical Properties of Reinforced Acrylic Resin Denture Base Material(An In Vitro Study).Al-Rafidain Dent J. 2009; 9(1):57-65.

[6] Vojdani,M and Giti R Polyamide as a Denture Base Material: A Literature ReviewJ Dent (Shiraz). 2015 Mar; 16(1): 1-9

[7] Kanie T, Fujii K, Arikawa H, and Inoue K. Flexural properties and impact strength of denture base polymer reinforced with woven glass fibers. Dent Mater. 2000;16:150-158.

[8] Knott NJ. The durability of acrylic complete denture bases in practice. Quintessence Int. 1989;20:341-343.

[9] Kamil NB.Effect of Addition of Different Length and Concentration of Silane Treated Glass Fibers on Some Properties of Heat cured Acrylic Resin. A Master Thesis, Department of Prosthodontics, University of Baghdad. 2008.

[10] Mahroo V., Rafat B., Amir A K. Effects of aluminum oxide addition on the flexural strength, surface hardness, and roughness of heat-polymerized acrylic resin Journal of Dental Sciences 2012; 7: 238-244.

[11] Neset VA., Hamdi A., Turan K., and Ilser T.Influence of various metal oxides on mechanical and physical properties of heat-cured polymethyl methacrylate denture base resins J AdvProsthodont 2013 ;5(3):241247.
[12] Jagger DC., Harrison A, and Jandt KD.Review: The reinforcement of dentures Journal of Oral Rehabilitation 1999; 26: 185-194.

[13] Power J.M. and Sakaguchi, R.L. Restorative Dental materials. $12^{\text {th }}$ ed. 2006 Ch. 7, 21: P. 149-157, 513-547.

[14] Anusavice K.J. Philips science of dental material. $11^{\text {th }}$ ed, Middle east and African edition $2008 \mathrm{Ch} 7, \mathrm{Ch} 22$, p: 143-166,721-756.

[15] Amy R. Elmore, former Scientific Analyst and Writer. Address correspondence to F. Alan Andersen, Cosmetic Ingredient Review International Journal of Toxicology 2003; 22(Suppl. 1):37-102.

[16] Pisaisit Chaijareenont ;Hidekazutakahashi ; Norihironishiyama and Mansuangarcsorrnukit : Effect of different amounts of 3methacryloxypropyltrimethoxysilane on the flexural properties and wear resistance of alumina reinforced PMMA. Dental Materials Journal 2012; 31(4): 623$628,627$.

[17] Shi J.; Bao Y.; Huang Z. and Weng Z. preparation of PMMA-Nanomater calcium carbonate composites by in-situ emulsion polymerization $J$. of zhejiang University Sci. 2004; 5(6) 709-713.

[18] ISO 179-1 .International organization for standardization; 2000.

[19] American Dental Association Specification No.12. Guide to dental materials and devices. 10th ed. Chicago;1999. p.32.

[20] Abdulkareem MM. The effect of adding metallic nano fillers on some properties of heat cure acrylic resin treated by microwave A Ph.D Thesis, Department of Prosthodontics, University of Mosel. 2016.

[21] Gopinadh A., Swetha H.B. O., Jyothi A., Sreedevi B., Parakash M., Sandeep C. The effect of aluminum oxide addition on the flexural strength of heat activated acrylic resin: An in vitro study Journal of Dr: NTR University of Health Sciences 2015; 4(1): 21-23.

[22] ChladekG. ŻmudzkiJ. BasaK. PaterA.Krawczyk C. Pakieła W. Effect of silica filler on properties of PMMA resin, Archives of Materials Science and Engineering 2015; 71 (2):63-72.

[23] Khalaf H A. Effect of Siwak on Certain Mechanical Properties of Acrylic Resin journal of oral research 2013; 1 (1):39-49.

[24] Ronak HC, and Parnav VM. Flexural properties and impact strength of denture base resins reinforced with micronized glass flakes. J Indian ProsthodontSoc 2016;16:264-70.

[25] Ali AM Evaluation of the effect of sodium fluoride addition on some mechanical properties of heat cure acrylic denture base materials J BaghColl Dentistry 2014; 26(4):9-13.

[26] Nidal W. Elshereksi, Saied H. Mohamed, AzlanArifin and Zainal A.M. Ishak Evaluation of the Mechanical and Radiopacity Properties of Poly (methyl methacrylate)/Barium Titanate-denture Base Composites Polymers \& Polymer Composites 2016; 24( 5).

[27] Abdulhamed AN. \& Mohammed AM. Evaluation of thermal conductivity of alumina reinforced heat cure acrylic resin and some other properties $\mathrm{J}$ BaghColl Dentistry 2010; 22(3):1-7.

\section{Volume 6 Issue 7, July 2017 www.ijsr.net}




\section{International Journal of Science and Research (IJSR) \\ ISSN (Online): 2319-7064 \\ Index Copernicus Value (2015): 78.96 | Impact Factor (2015): 6.391}

[28] Makarem AJ. Effects of aluminum oxide addition on the surface roughness and hardness of acrylic resin denture base Tikrit Journal for Dental Sciences 2015; 3 (1): 32-38.

Table 2: Mean, Standard deviation and ANOVA test of all tested sample

\begin{tabular}{|c|c|c|c|c|c|c|c|}
\hline \multicolumn{2}{|c|}{ Groups } & \multicolumn{2}{c|}{ impact strength test } & \multicolumn{2}{c|}{ surface hardness } & \multicolumn{2}{c|}{ surface roughness } \\
\hline concentration & $\mathrm{N}$ & Mean & Std. Dev & Mean & Std. Dev & Mean & Std. Dev \\
\hline $0 \%$ control & 10 & 0.205 & 0.043 & 72.382 & 1.723 & 2.194 & 0.209 \\
\hline $3 \% \mathrm{Al}_{2} \mathrm{SiO}_{5}$ & 10 & 0.288 & 0.020 & 75.576 & 1.395 & 2.682 & 0.732 \\
\hline $5 \% \mathrm{Al}_{2} \mathrm{SiO}_{5}$ & 10 & 0.156 & 0.012 & 77.91 & 2.248 & 3.336 & 0.097 \\
\hline $7 \% \mathrm{Al}_{2} \mathrm{SiO}_{5}$ & 10 & 0.12 & 0.026 & 79.594 & 1.183 & 3.624 & 0.247 \\
\hline $\begin{array}{c}\mathrm{ANOVA}_{2} \\
\text { test }\end{array}$ & F-test & \multicolumn{2}{|c|}{66.449} & 34.345 & 25.493 \\
\cline { 2 - 8 } & sig & \multicolumn{2}{c|}{0.000} & \multicolumn{2}{c}{0.000} & \multicolumn{2}{c}{.000} \\
\hline
\end{tabular}

Table 3: Multiple compressions (Bonferroni test) among all tested group for impact strength mean values KJ/M ${ }^{2}$

\begin{tabular}{|c|c|c|c|c|}
\hline \multirow{3}{*}{ Sample } & sample & $\begin{array}{c}\text { Mean } \\
\text { Difference }\end{array}$ & Std. Error & Sig. \\
\hline $0 \%$ control & $3 \% \mathrm{Al}_{2} \mathrm{SiO}_{5}$ & $-0.083^{*}$ & 0.0126 & .000 \\
\cline { 2 - 5 } & $5 \% \mathrm{Al}_{2} \mathrm{SiO}_{5}$ & $0.049^{*}$ & 0.0127 & 0.003 \\
\cline { 2 - 5 } & $7 \% \mathrm{Al}_{2} \mathrm{SiO}_{5}$ & $0.085^{*}$ & 0.0126 & 0 \\
\hline $3 \%$ & $5 \% \mathrm{Al}_{2} \mathrm{SiO}_{5}$ & $0.132^{*}$ & 0.0123 & 0 \\
\cline { 2 - 5 } & $7 \% \mathrm{Al}_{2} \mathrm{SiO}_{5}$ & $0.168^{*}$ & 0.0127 & 0 \\
\hline $5 \%$ & $4.00 \mathrm{Al}_{2} \mathrm{SiO}_{5}$ & $0.036^{*}$ & 0.0129 & .043 \\
\hline *The mean difference is significant at $\leq 0.05$ level. \\
\hline \multicolumn{6}{|l}{} \\
\hline
\end{tabular}

Table 4: Multiple compressions (Bonferroni test) among all tested groups for indentation hardness mean values

\begin{tabular}{|c|c|c|c|c|}
\hline Sample & Sample & Mean Difference & Std. Error & Sig. \\
\hline $0 \%$ & $3 \% \mathrm{Al}_{2} \mathrm{SiO}_{5}$ & $-3.194 *$ & .754 & .001 \\
control & $5 \% \mathrm{Al}_{2} \mathrm{SiO}_{5}$ & $-5.528 *$ & .754 & .001 \\
& $7 \% \mathrm{Al}_{2} \mathrm{SiO}_{5}$ & $-7.212 *$ & .754 & .000 \\
\hline $3 \%$ & $5 \% \mathrm{Al}_{2} \mathrm{SiO}_{5}$ & $-2.334 *$ & .754 & .023 \\
& $7 \% \mathrm{Al}_{2} \mathrm{SiO}_{5}$ & $-4.018 *$ & .754 & .000 \\
\hline $5 \%$ & $7 \% \mathrm{Al}_{2} \mathrm{SiO}_{5}$ & -1.684 & .754 & .191 \\
\hline \multicolumn{5}{|c|}{$*$ The mean difference is significant at $\leq 0.05$ level } \\
\hline
\end{tabular}

Table 5: Multiple compressions (Bonferroni test) among all tested group for surface roughness mean values $\mu \mathrm{m}$.

\begin{tabular}{|c|c|c|c|c|}
\hline Sample & Sample & $\begin{array}{c}\text { Mean } \\
\text { Difference }\end{array}$ & $\begin{array}{c}\text { Std. } \\
\text { Error }\end{array}$ & Sig. \\
\hline \multirow{2}{*}{$\begin{array}{c}0 \% \\
\text { Control }\end{array}$} & $3 \% \mathrm{Al}_{2} \mathrm{SiO}_{5}$ & -0.488 & 0.181 & .063 \\
\cline { 2 - 5 } & $5 \% \mathrm{Al}_{2} \mathrm{SiO}_{5}$ & $-1.142 *$ & 0.180 & .000 \\
\cline { 2 - 5 } & $7 \% \mathrm{Al}_{2} \mathrm{SiO}_{5}$ & $-1.430^{*}$ & 0.182 & .000 \\
\hline \multirow{2}{*}{$3 \%$} & $5 \% \mathrm{Al}_{2} \mathrm{SiO}_{5}$ & $0.654^{*}$ & 0.180 & .005 \\
\cline { 2 - 5 } & $7 \% \mathrm{Al}_{2} \mathrm{SiO}_{5}$ & $-0.942 *$ & 0.183 & .000 \\
\hline $5 \%$ & $7 \% \mathrm{Al}_{2} \mathrm{SiO}_{5}$ & -.288 & 0.181 & .716 \\
\hline
\end{tabular}

*The mean difference is significant at $\leq 0.05$ level

Volume 6 Issue 7, July 2017 www.ijsr.net

Licensed Under Creative Commons Attribution CC BY 